\title{
The Whistleblower Film - Is it a Genre and Why Does it Matter?
}

\author{
Saša Miletić \\ Freelancer, Austria
}

\begin{abstract}
In this paper I deal with the whistleblower film as a possible stand alone genre. Hollywood has a longstanding tradition of the whistleblower film, which is albeit "officially" not recognized as such, despite the fact that most of these films are well known classics. According to a list made by The Hollywood Reporter, there are around 20 films that can be considered whistleblower films, from On the Waterfront in the 1950s to Snowden in 2000s. They are rarely, if at all, described as whistleblowers films and not considered to belong to the same genre. It is therefore important to take a look at these films in order to examine the way whistleblowers are depicted, and thereby also take into account the ideologico-political context: do these films undermine the status quo of capitalism, or do they rather conform to it?
\end{abstract}

Keywords: Whistleblower, Hollywood, Genre, Ideology, Neoliberalism.

\section{Introduction}

Hollywood has a longstanding tradition of the whistleblower film, which is albeit "officially" not recognized as such, despite the fact that most of these films are well known classics like On the Waterfront (1954), All the President's Men (1976) or Silkwood (1983). The designation "whistleblower film" cannot be found on film sites like Imdb.com - Snowden (2013) for instance, a whistleblower film par excellence, is described as "biography, crime, drama." Although there is no literature dealing with them systematically, according to lists made by The Hollywood Reporter and, more recently, by Entertainment Weekly, as well as mentions in other websites and journals, whistleblower films do seem to generally be considered a genre (see Aquillina). Also, in a scholarly article, Olesen uses the term "whistleblower film" (2020), and gives a dramaturgical analysis which is useful in establishing the whistleblower film as a genre, to which I will refer later in the text. I would therefore like to argue that the whistleblower film can be considered a veritable standalone-genre that can be subject of exploration.

Although whistleblower films were not so numerous as other, more recognizable genres like the Crime film or Western, they have yielded a fair amount of films over the last seven decades that expose some of the crucial problems of the American society. Tod Haynes, director of one of the latest entries in the genre, Dark Waters (2019), seems to be very much aware of the type of film he was making: "I wanted to enter the vernacular and the tradition of the tense, brooding whistleblower films that make us look at systems of power and the instability of capitalist life" (Gilbey). Although Haynes describes the whistleblower film in general, the attributes "tense, brooding" may not be applicable for every whistleblower film. Films like Snowden, Silkwood or Informant! (2009) are very different in tone and style since they combine different genres.

Although the case seems clear, I will nevertheless in this paper ask the question if whistleblower film can be considered a genre and explore it not only from the perspective of genre theory, mainly using Rick Altman's semantic/syntactic approach, but also from a politico-ideological perspective in order to try to define what the traits of this genre are and why is it useful do deal with it. If and how much the whistleblower film is critical of the "capitalist life," or even of capitalism as such, is also a question I will turn to in the paper.

\section{The Whistleblower}

Before I delve into the genre analysis, I want to establish the term whistleblower more clearly. As Vandekerckhove et al. state, the widespread use of the term as it is understood today started in the 1970s (39). According to Merriam-Webster dictionary, a whistleblower is "an employee who brings wrongdoing by an employer or other employees to the attention of a government or law enforcement agency." In his Whistleblower's Handbook, Kohn writes: "Who are these whistleblowers? Sometimes they are people you read about with admiration in the newspaper. Other times they are your coworkers or neighbors. However, most whistleblowers are regular workers performing their jobs" (xi). Many scholars that deal with whistleblowing connect it to Foucault's notion of parrhesia, which is translated as "frankly speaking truth" (Vandekerckhove and Langenberg 36), and define whistleblowing then also as "truth telling in the workplace" (Mansbach in Weiskopf and Tobias-Miersch 1622). Mansbachs approaches whistleblowing also from the aspect of parrhesia as 'fearless speech' which is the "disclosure of the illegal or morally wrong deeds or practices by powerful actors that result in harm to the public. This speech is fearless because, even though the wrongdoers are in a position to hurt the individual making the disclosure, he or she chooses to do it anyway" (12). He further states that "(...) though whistleblowing as fearless speech is a micropolitical practice, and as such, does not have the same political effects as collective democratic action, such as voting, demonstrating, or going on strike, it nonetheless keeps liberal democracies vibrant" (12).

The whistleblower, in my view, is an employee who becomes disloyal to his/hers previous "cause" and employer, and becomes loyal to the new cause 
which might oppose everything he/she previously officially believed or worked for. Daniel Ellsberg, the whistleblower who leaked the "Pentagon Papers" concerning the Vietnam war in the 1970s, describes this shifting of loyalty:

Most of us had seen our going (to Vietnam) as the response of loyal Americans to our President; until recently, few had supposed that might conflict with serving the legitimate interests of our country. What was needed now, to go beyond that reflex response, was the inspiration to find in oneself loyalties long unconsulted, deeper and broader than loyalty to the President: loyalty to America's founding concepts, to our Constitutional system, to countrymen, to one's own humanity - and to our 'allies,' the people we were bombing (38).

The problem with narratives that deal with whistleblowing is that the focus inevitably shifts from the (mostly) systemic problem (corruption, global surveillance, war crimes, etc.) to the whistleblower as an individual. Moretti finds that the interest of the media regarding whistleblowing, if one compares the reactions to the Pentagon Papers and to Edward Snowden's discoveries about the NSA, shifted over the years from the reveals to the individual. Referring to Ellsberg, Moretti writes that: "(...) the legitimate questions were not about him and what motivated him, but rather inquiry on (among other items) the relationship between government and media; whether the US would be damaged militarily or diplomatically because of the release of the papers (...)" (8).

Vandekerckhove and Langenberg also stress the importance of not focusing on the speaker. The focus should rather be on the act of speaking out itself, "where the truth lies in the irreversible fact that someone has said this. There is no way to go back to the moment where nobody had spoken the critique" (39). Snowden was also fully aware of the problem of the media focusing on the whistleblower as a person, as he was interviewed by Glenn Greenwald, who wanted Snowden to talk about himself, which he rejected from the get-go: "The modern media has a big focus on personalities and I'm a little concerned the more we focus on that the more they're gonna use that as a distraction (...)l'm not the story here" (Citizenfour).

This shift of interest goes along, according to Moretti, with the corporate ownership of media (7), where profit is the primary goal and therefore sensationalism is the order of the day, which is inextricably linked to the focus on the "scandalous" individual. As I will argue in the final chapters of this paper, this view is being reinforced in film, whistleblowing is seen from individualistic perspective (Weiskopf and Tobias-Miersch 1622). This is one of crucial points when dealing with the whistleblower film - the figure of the whistleblower, the focus on the individual and the connection of this approach to neoliberal ideology of our societies today. Here I rely on David Harvey's definition of neoliberalism:
Neoliberalism is in the first instance a theory of political economic practices that proposes that human well-being can best be advanced by liberating individual entrepreneurial freedoms and skills within an institutional framework characterized by strong private property rights, free markets, and free trade (...) (71).

This definition can be supplemented by Shoshana Zuboff's concise observation that the neoliberal ideology of individualism "shifts all responsibility for success or failure to a mythical, atomized, isolated individual, doomed to a life of perpetual competition and disconnected from relationships, community, and society" (33). In other words, the individual is supposedly the alpha and omega of the neoliberal capitalist system, and Hollywood films tend to reflect this ideal.

\section{The Genre Question}

\section{Defining the Genre}

Films, whether they were made in Hollywood, independent or otherwise, mostly combine different genres and cannot therefore be easily pinpointed to only one. Also, as Basinger writes, "no one film ever appears that is quintessentially the genre [emphasis in original]. A group of films with very similar characteristics emerge, blend, and become one film in memory. When later filmmakers create films of the same type (...) they make the memory of the accumulated film" (17). It is also important to supplement this with Altman's remark that "we need to recognize that not all genre films relate to their genre in the same way or to the same extent" (34).

The "mixing" of genres is almost more often the case than producing films that are "pure," films more often than not "combin[e] the syntax of one genre with the semantics of another" (Altman 34). This can be witnessed most clearly in films like The Electric Horseman (1979), where the iconography of a Western is displaced into another genre (Drama, Romance) and also another time, the late $20^{\text {th }}$ century. Furthermore, any film can be seen from a certain perspective that enables to categorize it in a different way and to designate different genre description(s) to it - Erin Brockovich (2000) for instance, which is also considered a whistleblower film, is described by Bingham as "social problem biopic comedy" (347), but since it deals with lawyers and a court case, it can also be considered as a courtroom drama or legal drama (see Miletic 2017). Still, the contention that it is a biopic could hold, since it focuses on one portion of a life of a famous or "important" person and also has the true story aspect, "the introductory assertion of the truth" (Custen 51).

When dealing with genre definitions, the point is not to fixate a certain film in a certain genre (or genres) and provide a definitive designation or label, but to provide a possible new point of view on a certain film. A film like All the President's Men can be considered a political thriller, and can also be seen solely from a point of view 
of journalism. To regard it as a whistleblower film is adding another layer, another legitimate point of view. Clearly, All the President's Men is not a horror film or a comedy, it is not Sci-Fi, it does not happen in space, there is no huge monster attacking the city. All this "negative properties" can also help us to narrow down what kind of a film we are dealing with. If regarding such a film as a whistleblower film is a far reach as describing it as a monster movie (or a porn for that matter, because of the "deep throat" connection), than we are definitely on a wrong path.

As Bordwell and Thompson state, genres are "convenient terms that develop informally. Filmmakers, industry decision makers, critics, and viewers all contribute to the formation of a shared sense that certain films resemble one another in significant ways" (328). According to Bordwell, genres are mostly identified through subject matter or theme, manner of presentation/iconography, plot patterns or emotional effect (328f). This approach is similar to Rick Altman's syntactic/semantic approach to genre, where

we can as a whole distinguish between generic definitions that depend on a list of common traits, attitudes, characters, shots, locations, sets, and the like - thus stressing the semantic elements that make up the genre - and the definitions that play up instead certain constitutive relationships between undesignated and variable placeholders - relationships that might be called the genre's fundamental syntax. The semantic approach thus stresses the genre's building blocks, while the syntactic view privileges the structures into which they are arranged (31).

Altman also contends that some genres do not develop a "stable syntax" like "reporter, catastrophe, big caper" (39). They therefore have the tendency to "disappear," or become rare, while some genres are more durable. Here must be added that for instance Westerns and Musicals, which Altman sees as durable, have also struggled and became a rarity in the last thirty years, although it can be said that they to a certain point do persist.

\section{Framing}

As Bordwell contends, one can regard a film from many different perspectives, or "frame" it: "as a fiction, as a Hollywood movie, as a comedy, as a Steve Martin movie, as a 'summer movie' and so on" (146). This sort of framing is for instance quite noticeable on the Netflix streaming service. If we take a look at at genres that can be chosen from in the film menu, besides the well known ones like Action, Comedy or Horror, one can also choose between "Hollywood," "Independent" or "International." These three categories are clearly not genres in conventional sense, but are there to provide certain orientation - before customers can choose which genre exactly to watch, they first have to choose if they are going to watch a Hollywood film, probably meaning first and foremost a commercial blockbuster, or an independent one, a less conventional (in comparison to Hollywood), more "niche" kind of film. This clearly illustrates Hassler-Forest's statement that "(...) genre is not so much a classificatory tool as it is a way of grouping diverse texts together, frequently in order to increase their commodity value" (7).

It is also useful to look at the descriptions of the particular films themselves: some films, besides sometimes rather cryptic descriptions like "slick," or ostensibly more accessible like "inspiring," "cerebral" or "magical" - there are also more concrete genre descriptions like Western or Film Noir, which do not appear in the main genre menu. In the search field, it is possible to type in "Western" and as a result get Westerns, and also other genres that the algorithm deems appropriate. These classic genres are not in the main menu probably because there are not as many new Westerns and especially Film Noirs around anymore in general and also not on Netflix. But it is still possible to find or stumble upon them.

All these examples show how flawed a rigid genre concept can be, and also the need for more than one perspective on a certain film. A simple genre denomination is most of the time not enough. This means that the genre is only one way of looking at a film when it comes to making a choice, but also when it comes to serious analysis: categorizing in a sense is important, since one can choose to write a book or an article on Meryl Streep films (thereby maybe even ad hoc defining a genre called "Meryl-Streep-Film"), or courtroom dramas, 1990s films in general, or films about nature.

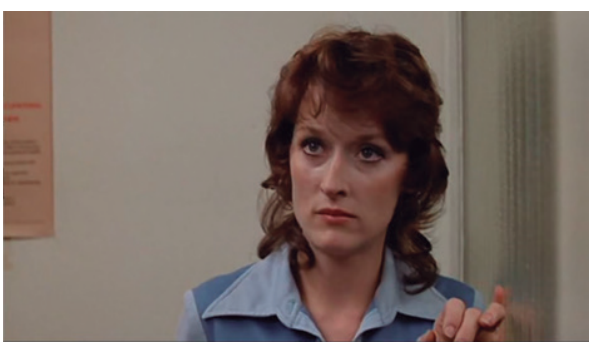

Image 1- It could be any genre: Meryl Streep in Silkwood.

Genre therefore needs always to be seen in a certain context - if for instance a recognized auteur filmmaker deals with a certain genre, then we can look at this film not only from a genre perspective, but also from the auteur perspective - a WWII film is not the same when made by Steven Spielberg or by Quentin Tarantino; The Shining (1980) is a horror film, but also a Stanley Kubrick film; by the same token, comedies by the Marx Brothers are not the same as those made by the Farelly Brothers; If this seems as too obvious a point, it is still important not to forget that the "framing" of a film always depends on many factors. The question is what we mean when we first and foremost think of a genre, and utter a statement: I want to watch a "Horror" film? Almost immediately other factors come into play: is it 
going to be A Nightmare on Elm Street (1984), or rather one of more recent productions like It Follows (2014)? In the case of the latter even a controversy might ensue around the question if this is a "traditional" horror film or a so called "post Horror" (see Church). When regarded from this perspective, a one-word-genre-designation is almost never enough; to nevertheless reduce a film to a certain genre therefore needs to serve a concrete aim. For the purpose of an analysis of the whistleblower film then, the genre perspective becomes the focal point, its conventions and the questions that arise from it, be it from a historical or politico-ideological perspective are of importance.

One of the reasons to explore a genre is to look at syntactic/semantic properties that not only point to certain genre traits, but also to political/ideological ones. These can be of course sought after in any film, but it is pertinent to engage with such analysis with films that consciously deal with political and social issues. Here the political/ideological is at the same time part of the text and subtext. For instance, a film that deals with water pollution or sexual harassment openly deals with a political/ideological/social subject matter; at the same time the way the film deals with this subject is on another politico-ideological level (for instance are police films critical of police work or rather proponents of "law and order" or even vigilantism?).

This of course does not mean that genre can be inherently conservative or progressive, and proclaiming to deal with a subject matter that is of general concern or even overtly from a liberal/even leftist perspective, does not mean that a certain film cannot succumb to the "ruling ideology," to put it in an old fashioned way. Basinger, in examining the World War II Combat film deals with this question: "Genre is a kind of a Lego set (...) The combat film pieces can be put together as a propaganda machine or as an anti-propaganda machine, as an 'America is beautiful' or an 'America is an imperialist dog' message." She also contends that "(...) shifting ideology is central to genre's purpose and construction" (15).

\section{The Whistleblower Film}

It would be rather easy to make a case against the whistleblower film as a genre on a superficial level. From a strictly semantic point of view, the films are not instantly recognizable, as for instance Westerns or police procedurals might be; Courtroom Dramas revolve around lawyers in three piece suits and a briefcase, or a woman in a similar attire; there are no typical sets or set ups, like the courtroom, or the library where the engaged lawyer pours over a heap of thick law books. Cops and gangsters are also instantly recognizable through their attire and other trade marks. In Horror there is almost always (some kind of) a recognizable monster/killer. The whistleblower film on the other hand lacks those instantly recognizable traits. As in Serpico the protagonist can be a cop or in Silkwood a worker in a plutonium processing plant. One of the traits of a whistleblower is therefore a negative one: although the job is relevant for the narrative, the whistleblower can work in any job. The image of Edward Snowden for instance copying files from the computer in Snowden could be a part of a techno thriller or even a romantic comedy for that matter. A scene in Informant! where a hidden camera is installed to film a secret meeting between executives could be from a spy film. The whistleblower film is therefore first and foremost recognized pragmatically, as Hassler-Forest writes, they are "texts that are written and talked about as part of an existing (...) genre" (8). As already noted above, the whistleblower film is in journalism already recognized as a standalone genre. It can be therefore concluded that, following Altman, the whistleblower film is mostly defined by the syntax, not the semantics.

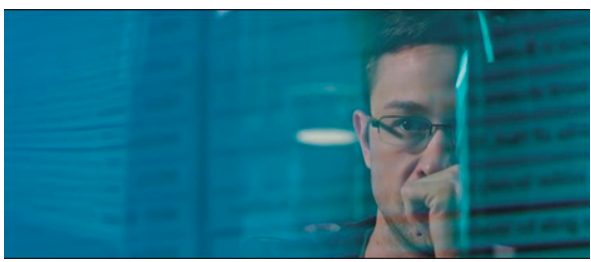

Image 2- The thrill of copying files: Joseph Gordon-Levitt as Snowden.

Relying on theories put forth by Campbell and Propp on the "hero's journey," Olesen (415) makes a crucial contribution to the study of the whistleblower film as he identifies a hero's journey of the whistleblower that at the same time constitutes a dramaturgical pattern of the whistleblower film: "(1) discovery of wrongdoing; (2) search for internal rectification; (3) experience of retaliation; (4) shifting loyalties; and (5) public disclosure." These five steps can be found in almost every whistleblower film, with shifting emphasis on each of the points. Apart from this, I would like to point out further thematic traits that can be detected within this genre: the job negation, the hero/villain trajectory and the negotiation of public and private sphere, which I will explore separately in the next chapter.

To briefly summarize: whistleblower films revolve around an employee who decides to uncover wrongdoings by his/her employer, and show the struggle for the truth to come out, the repercussions and whistleblower's efforts to stay safe. There is also usually a "helper" (Olesen) figure, a reporter for instance, who follows the whistleblower on his/her path. Depending on the case, the films end with the reveal of the wrongdoings and sometimes the vindication of the whistleblower. These films also revolve around an important issue - nuclear energy, pollution, tobacco industry etc.

Furthermore, the whistleblower film can be divided into two subcategories: the films centered around the figure of the whistleblower like Serpico, Silkwood, Snowden, etc., and films that deal with whistleblowers indirectly, but still can be considered to be a part of 
the genre, since they show the whistleblowers and their helpers in tandem, like All the President's Men, The China Syndrome (1979) or, albeit in an altogether different tone, The Fifth Estate (2013). Although Silkwood or On the Waterfront, apart from being whistleblower films, can also be framed as social dramas rather than political thrillers, they share some of the properties of the political thriller, as for instance the most important one stated by Koebner and Wulff: the fight between the oppressor and the oppressed, or the weak against the strong; the fight against the "moloch" of the state apparatus (15) and other power structures.

\section{Three Distinct Motifs}

\section{The Job Negation}

The thematization of the negation of the employee's identification with their job which sets this genre apart from many others, since many film genres revolve around a certain job description: cowboy, journalist, cop, lawyer, FBI agent, etc. The job of the main character is in this case not "just a job," but the characters obsession, as for instance Kronemeyer notes that an important part of the Woodward and Bernstein Watergate investigations, as depicted in All the President's Men, is first and foremost their enthusiasm, zeal and their drive to succeed in their journalist work (232). Bradshaw also notes the importance of this attitude in Official Secrets: "[the protagonist] has an idealism, work ethic and professionalism that made her an excellent intelligence operative in the first place, and yet it is precisely these things that made her rebel" (Bradshaw). The act of whistleblowing seems to be therefore a dialectical reversal, the same thing that enables an employee to be excellent in his/her job also serves as a powerful weapon against their former employers, of course with dire consequences.

What a character in a film does for living is of importance since it is, pragmatically, the quickest and easiest way to describe a character, but it is also ideologically most effective - work is important, without it you are "nothing." Therefore, when the whistleblower decides to act, he/she then, as Olesen writes, "almost erases him[/her]self" (418). A transformation happens, somewhat ironically akin to the genre of horror: the transformation of an employee into a whistleblower is a horror-scenario for every (problematic) employer. This negation of the job can be read as the negation of the "American dream" and is what distinguishes the whistleblower film from other genres and is one of its most prominent genre traits. The ideological function of work, the personal stability, providing for family, the "pursuit of happiness" that is ever present and of importance to a different degree in almost any Hollywood film is turned on its head: instead of a committed, almost fanatical worker in a capitalist society we see someone who gives all that up. Whistleblowing in film can therefore be seen as a non-job, at the same time potentially an asocial position, a certain falling out outside of society, while at the same time being a civic duty, something done for the benefit of the society, the "civil sphere" (Olesen 418). It is important to note that exactly this tension between being a part of the productive capitalist society and becoming its nemesis is what distinguishes Snowden from Julian Assange: Snowden was working for the government, Assange was and still is an outsider, and not a whistleblower per se. Snowden's "betrayal" might be seen as more problematic for the general public in America, although Assange is considered as dangerous for platforming the whistleblowers and working closely with them, being a helper, and more than that, someone who is not a journalist but completely independent from the mainstream discourse. Assange cannot therefore in The Fifth Estate conform to the cliché of being a devoted worker who then turned against his employers, there is no easy point of identification with him as a character, which might be there even if one does not agree with Snowden's actions but can relate on the level of the job.

\section{Heroes/Villains}

A further distinctive aspect of the whistleblower film is the hero/villain trajectory in the depiction of the whistleblower. The act of betrayal or treason is essential for whistleblowing, since whistleblowers are generally described as either "heroes" or "traitors" (Weiskopf and Tobias-Miersch 1622). Betrayal is traditionally not considered to be the work of a hero/ heroine - in conventional fictional and non-fictional narratives, a person who betrays somebody needs to be a villain. There are of course many well-known examples of that, like Judas' "diabolic" (Krischer 2019) betrayal of Christ or Brutus' betrayal of Caesar. There are also many famous examples of betrayals in Hollywood films: The main storyline of the Star Wars Episodes I-III (1999-2005) shows the character arc of Anakin Skywalker becoming a villain, Darth Vader, by betraying not only his Jedi ways but also his best friend and mentor, Obi Wan Kenobi, in the process. Betrayal is here again a villainous act, something that is depicted and perceived as unequivocally bad. Even if in some other films there might be a depiction of betrayal as a good deed (one could think of such films as Valkyrie (2008), about the failed assassination of Hitler in 1944), here it is crucial to the genre.

Krischer argues that in reality the notion of treason is not used as an argument in the court of law anymore, and that Snowden for instance would probably not be tried for treason (although definitely for something else), and the case of Chelsea Manning shows that a "traitor" can even be "pardoned" (28) - or in this case get the sentence commuted (Savage). Still, treason or betrayal carry an emotional load, an archaic but still present meaning with them and are useful narratives in film, even when generally considered as obsolete or overcome in judicial sense.

My proposal here is that in the whistleblower film, the notion of villainous betrayal is turned on its head - the narratives effectively celebrate betrayal, the switching of the sides, the shifting of loyalties. The hitherto loyal 
employee commits a "villainous" act and through this act he/she becomes a hero/heroine. Their heroism is of course never absolute - they will always be "heroes for some, villains/traitors to others." And not only for their former employees, since the question of their character can always be raised by their potential next employer - "will they do it again, can I rely on them?" in accordance with a quote attributed to Julius Caesar: "Proditionem amo, proditores non laudo," which is commonly translated as "I love the treason but I do not praise the traitor" (Brittnacher 11). For instance, in On the Waterfront the protagonist, Terry Malloy (Marlon Brando), finally decides to blow the whistle on his employer, the mobster/union boss Johnny Friendly (Lee J. Cobb), but only after Friendly kills his brother. In this first whistleblower film, the crucial internal conflict of the whistleblower is depicted - although everyone will mark him as a "stool pigeon," Malloy still decides to testify against Friendly in court. The film lays the groundwork for what can be regarded as an almost transgressive and, for Hollywood, atypical depiction of a protagonist who becomes a hero through an act of betrayal in the whistleblower film in general.

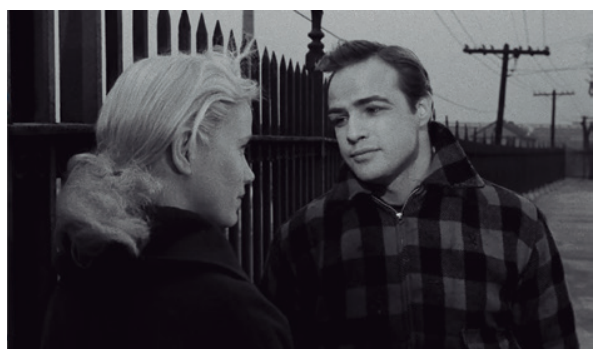

Image 3 - The Hero is the Traitor: Marlon Brando and Eve Marie-Saint in On The Waterfront.

Still, although the films do have these transgressional moments, in the end, they do conform to neoliberal ideology. Snowden for instance depicts a whistleblower as a typical Oliver-Stone-hero, a "disillusioned idealist" (Scott). In Stone's most political films, which are generally considered to be liberal and critical of American politics, we actually witness the all-American patriot being disillusioned by certain historical events, as in Platoon (1986) or Born on the $4^{\text {th }}$ of July (1989) which makes him question the government and its actions. This is important not only regarding personal traits but also political views of the character. There needs to be no doubt in the mind of (first and foremost) Americans that the protagonists of the aforementioned films are "cowards" or, most importantly, unpatriotic. This is something that is supposed to appeal to the general audience and is not only visible in Snowden but also in other whistleblower films. They, like the dissidents mentioned before, are also believers in the system but that believe "too much." A film like Snowden profits from this ambivalence in Snowden's (Joseph Gordon-Levitt) own political stance as it is shown in the film (first he is more right wing, then, after meeting his future partner Lindsey Mills (Shailene Woodley), turns slightly to the left), and also in the ambiguity of the film itself, as Stone stated already about his Vietnam war film Platoon that "it could be embraced by (...) the right and the left. Essentially, most movies make their money in the middle" (Banff Centre). Nevertheless, in the case of Snowden, we are dealing with someone who cannot simply be redeemed as a patriot who did his duty. For many Americans and for the government, he will probably be still remembered as a villain. Even if the whistleblower is someone "pure" or at least not a "problematic" person like Snowden (i. e. without any private scandals), he still remains a problem for the American government and probably the public opinion. According to Greenwald, the majority of the people in the US, according to some surveys, still want to see Snowden in prison, even if they find that the surveillance by the NSA was wrong (365).

The question of character is also at the center of The Informant!, which revolves around a very unreliable whistleblower, Mark Whitacre (Matt Damon), who uncovered price fixing in the American food industry in the 1990s. While working as an informant for the FBI and providing them with audio and video material of his superiors, he also managed to embezzle millions of dollars from his company, and was convicted for it. The film shows Whitacre as a pathological liar who constantly baffles the FBI agents he is working for with his lies and deception. Whitacre is an example of a "villainous hero," he is a whistleblower who uncovered the price fixing and took on big business but is not "pure." This time around though, there is no redeeming ending for the character as in many other whistleblower films. The Informant! shows a protagonist who is not quite suitable for being a classic "American hero."

The traits that have equal importance "on the street," between gangsters and in the world of regular employment at the same time, like loyalty and secrecy, are the ones that are put into question by the whistleblower. From that perspective, the whistleblower can appear as a dishonest person, their motives can always be put into question. No matter how important the disclosures, the person can be easily disqualified and smeared by his/her enemies and become tainted by the deed itself.

\section{Private/Public}

Films based on the real events and persons, living or dead, and the whistleblower films are almost exclusively invasive, they show intimate moments of a person's life that might or might not be favorable to the person depicted, under the guise of truth telling, which can be, and mostly is, subjective. The question that should be posed here is: why is it important that we know details of someone's private life at all? Is it simply to understand his/her actions better or is there also ideology at play? Here is a radical move needed: a questioning of the need to examine someone's life so closely, and especially in connection with the act of whistleblowing that is supposed to be regarded separately - the seemingly banal question should be posed: what is more important Snowden's private life or the revelations he has made? 
The negotiation between private and public is inherent to the whistleblower film, since it is not only that the whistleblower reveals wrongdoings of others, but he/she is also revealed. The private life suddenly becomes relevant, because it can be weaponized and used against the whistleblower. The whistleblower film does show in most cases that there should be a clear distinction between what is private and what public, and also that it should not matter how a person "really" is (Silkwood, Informant!, North Country (2005)). In my opinion, this has limits. A whistleblower's private life should be considered as irrelevant, but it does not hurt for someone like Snowden to be a "straight arrow," a true "ordinary guy" ("Good Manners") with whom the audiences might connect more easily, as it is the case in Snowden, than with a "controversial" figure like Julian Assange. It is also of importance, and at the same time a commonplace, for a mainstream Hollywood film that the protagonist is relatable in order for the audiences to sympathize with him/her (Bordwell and Thompson 82). This is important not only regarding personal traits but, I would argue, also political views of the character. There needs to be no doubt in the mind of American audiences when it comes to films that deal with politics and similar subjects, that the protagonists are, in the end, patriots.

Problems arise with someone like Assange, who is depicted as elusive, "mysterious" and egoistic in The Fifth Estate. Here, instead of focusing on the work, it is "the man" who becomes the focus of attention. The private becomes public, the personal becomes scrutinized, the notion of whistleblowing is turned on its head. The conclusion is that Assange's quest is strictly a personal one and that in the end "everyone has secrets," as it is explicitly stated in the film (and could be its motto). Does this imply that if everyone has secrets, then "everyone" should also strive for privacy - private persons, government and corporations, institutions that are also composed of "people"?

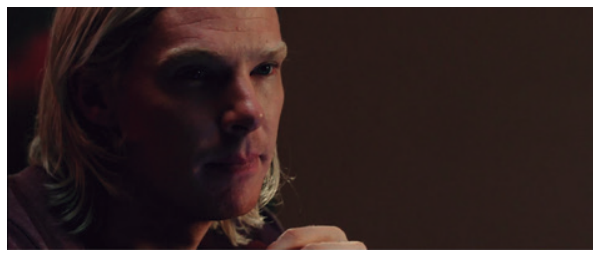

Image 4 - The "problematic" individual: Benedict Cumberbatch as Assange in The Fifth Estate.

This is where the transgressive potential of the whistleblower film meets what Slavoj Žižek calls "Hollywood ideology" ("Good Manners") and also ideology of our neoliberal societies. The true underlying conflict here is between classic journalism, where the journalists can publish their pieces and get the acclaim for discovering the "new Pentagon Papers," once again ensuring the freedom of the press and inter-systemic critique. This way of working of the press, as the films show, always pays off, all the while, in reality, very little changes since, as Žižek writes, the "formal functioning of power" stays in place. He further states about WikiLeaks:

The true targets here weren't the dirty details and the individuals responsible for them; not those in power, in other words, so much as power itself, its structure. We shouldn't forget that power comprises not only institutions and their rules, but also legitimate ('normal') ways of challenging it (an independent press, NGOs, etc.) ("Good Manners").

Here again is Foucault's notion of parrhesia of importance as opposed to "institutionalized critique" - the speaker, the parrhesiast, is an "unexpected source of critique" (Vandekerckhove and Langenberg 39 ), this is where the difference lies, and this does not only concern institutionalized whistleblowing within a firm for instance, but also conventional journalism. As long as the whistleblower works within institutions, he still might not be absolved by the state, but he/she is still within the limits of what is "normal" public space. Many whistleblower films involve journalists, and the revelation of the wrongdoing seems to be the endpoint, the goal that is supposed to be achieved not in order to question the power, ultimately, but to ensure the functioning of power as it is. In this way, the power structures and their ideology are still a closed circuit with its own sense of "privacy."

\section{Conclusion}

The whistleblower film, besides being a veritable Hollywood film genre also deals with certain problems of the American society and societies in general, the relation of public and private, the work ethic, the questioning of power and the notion of betrayal. The hero/villain trajectory that is an undercurrent within this genre seems to be its most potent and transgressional aspect, even if these films are the product of the Hollywood system. Since On the Waterfront, this genre celebrates betrayal, the shifting of loyalties, the changing of sides and an unusual relationship to work that defies, even negates the "American Dream" - whereas many film genres celebrate the devotion of employees to their jobs, this one celebrates the ones who opt against their job and the pursuit of happiness itself. But can this genre be considered transgressive in itself, or even progressive, does it question the ideology of Hollywood, American ideology or even capitalism itself? Here problems arise. The transgressional moment, which is clearly present, is compensated by neoliberal ideology which celebrates individualism. The whistleblower is in the end the celebrated hero, the individual against the system, but only if there is potential within the character of the particular whistleblower to be such a hero. What betrays the ideology of most of these films is its ending, as Žižek writes about the ideology of Hollywood blockbusters like 
All the President's Men and The Pelican Brief, in which a couple of ordinary guys discover a scandal which reaches up to the president, forcing him to step down. Corruption is shown to reach the very top, yet the ideology of such works resides in their upbeat final message: what a great country ours must be, when a couple of ordinary guys like you and me can bring down the president, the mightiest man on Earth! ("Good Manners")

Here lies the importance of exploring the whistleblower film as a genre: not to simply celebrate the "unsung heroes" or look for emancipatory potential of some of its narrative components, but also to take a look at the notion of the quest for truth as such. Žižek expresses the problem of revealing the truth in our day and age by referring to the famous fable "The Emperor's New Clothes," where a child is the only one who is naive and brave enough to state that the emperor is in fact naked. But for Žižek today,

in our cynical era, such strategy no longer works, it has lost its disturbing power, since everyone now proclaims that the emperor is naked (that Western democracies are torturing terrorist suspects, that wars are fought for profit, etc., etc.), and yet nothing happens, nobody seems to mind, the system just goes on functioning as if the emperor were fully dressed (Less than Nothing 92).

The choice that the whistleblower faces is between the universal notion of treason, as something deplorable as such, and his particular situation. At the same time, his particularity (hides) another universal meaning, which is beholden to truth, to what is right or wrong. The choices are to either (1)stay and let the wrongdoings go on, to distance themselves from the situation, or (2) another individualistic approach, to quit the job and personally subtract themselves from the situation, thereby keeping their inner integrity in tact and also apart from the society. An individualist conundrum is at play here: it is the (neoliberal) individual that can alert the community and maybe even influence a change in society; at the same time, if he/she does that and changes do not happen the way it was expected or at all, than we again must conclude that the individual cannot really influence the society, the system, the government, since the institutions are too powerful. The films reinforce the belief in the "holy" individual, a whistleblower as a "secular hero or saint," (Grant 2002 in Olesen 415), while at the same time in reality we see that this is doomed to fail. An individual can cause a stir, but when nothing changes systemically, then the sacrifice might have been in vain, the whistleblowers, if they manage to keep their freedom, might become just another "talking head," a pundit, who literally disappear in the vastness of internet, and whose contentions in the worst case scenario might be read as another conspiracy theory. In the search for "the truth," as Žižek points out, we should not fetishize the truth (Frontline Club), because exactly this, paradoxically, might lead us astray. It is also important no to fetishize the whistleblower as the ultimate American hero - a lone gunman or vigilante.
To explore the whistleblower genre therefore means to confront a genre made in Hollywood whose politics might have some progressive potential, but at the same time realizing that this potential is wrapped into an ideological, shiny wrapping paper.

\section{Bibliography}

Altman, Rick. 2000. "A Semantic/Syntactic Approach to Film Genre." In Film and Theory: An Anthology, edited by Stam Robert and Toby Miller, 179-91. Hoboken: Blackwell.

Aquillina, Tyler. 2019. "20 Whistleblower Movies to Watch: All the President's Men, The Report, and More." The Hollywood Reporter. https://www.hollywoodreporter. com/gallery/21-best-movies-whistleblowers-578755/17the-informant-2009. Last access 20/04/2021.

Banff Centre for Arts and Creativity. 2013. "Oliver Stone: Satire and Controversy." https://www.youtube.com/ watch?v=7s2gBKApxyk\&t=7s. Last access 20/04/2021.

Basinger, Jeanine. 2003. The World War I/ Combat Film: Anatomy of a Genre. Middletown: Wesleyan University Press.

Bingham, Dennis. 2010. Whose Lives Are They Anyway? The Biopic as Contemporary Film Genre. Piscataway: Rutgers University Press.

Bordwell, David. 1989. Making Meaning: Inference and Rhetoric in the Interpretation of Cinema. Cambridge: Harvard University Press.

Bordwell, David and Kristin Thomson. 2010. Film Art: An Introduction. New York: McGraw-Hill.

Bradshaw, Peter. 2019. "Official Secrets Review - Keira Knightley Shines as a Very British Whistleblower." The Guardian. https://www.theguardian.com/film/2019/oct/18/ official-secrets-review-keira-knightley-whistleblower. Last access 20/04/2021.

Brittnacher, Hans Richard. 2015. "Über Verräter - Zur Einleitung." In Verräter, edited by Hans Richard Brittnacher, 7-16. München: Richard Boorberg Verlag.

Church, David. 2021. Post Horror: Art, Genre and Cultural Elevation. Edinburgh: Edinburgh University Press.

Custen, George F. 1992. Bio/Pics: How Hollywood Constructed Public History. New Brunswick: Rutgers University Press.

Ellsberg, Daniel. 1972. Papers on the War. New York: Simon and Shuster.

Frontline Club. 2012. "Julian Assange in conversation with Slavoj Žižek moderated by Democracy Now's Amy Goodman." https://www.youtube.com/watch?v= j1Xm08uTSDQ\&t=4235s. Last access 20/04/2021.

Gilbey, Ryan. 2020. "Todd Haynes: "People Who Say Trump is Bound to Win are Letting it Happen." The Guardian. https://www.theguardian.com/film/2020/feb/26/ todd-haynes-interview-dark-waters-dupont-pollution. Last access 20/04/2021.

Greenwald, Glenn. 2015. Die globale Überwachung: Der Fall Snowden, die amerikanischen Geheimdienste und die Folgen. München: Knaur.

Harvey, David. 2015. "A Brief History of Neoliberalism." In The Globalization Reader, edited by Frank J. Lechner and John Boli, 71-76. Hoboken: John Wiley \& Sons.

Hassler-Forrest, Dan. 2012. Capitalist Superheroes: Caped Crusaders in the Neoliberal Age. Winchester/ Washington: Zero Books.

Koebner, Thomas and Hans Jürgen Wulff (eds). 2013. Filmgenres: Thriller. Stuttgart: Reclam. 
Kohn, Stephen Martin. 2011. The Whistleblower's Handbook: A Step-By-Step Guide to Doing What's Right and Protecting Yourself. Guilford: Lyons Press.

Kronemeyer, Nadja. 2013. "Die Unbestechlichen" (All the President's Men). In Filmgenres: Thriller, edited by Koebner, Thomas and Hans Jürgen Wulff, 232-235. Stuttgart: Reclam.

Krischer, André. 2019. "Von Judas bis zum Unwort des Jahres 2016: Verrat als Deutungsmuster und seine Deutungsrahmen im Wandel: Eine Einleitung." In Verräter: Geschichte eines Deutungsmusters, edited by André Krischer, 2-16. Wien, Böhlau.

Miletić, Saša. 2019. Hollywoods Gerechtigkeit: Gerichtsiflme der 1990er - Ästhetik, Ideologie, Dramaturgie. Wien: LIT Verlag.

Moretti, Anthony. 2013. "Whistleblower or Traitor: Edward Snowden, Daniel Ellsberg and the Power of Media Celebrity." Communication presented at Moscow Readings Conference, Moscow, Russia, 14-15 November.

Olesen, Thomas. 2020. "The Whistleblower Hero in Cinematic Dramatization." In The Sociological Review 69: 414-433.

Savage, Charlie. 2017. "Chelsea Manning to Be Released Early as Obama Commutes Sentence." The New York Times. https://www.nytimes.com/2017/01/17/ us/politics/obama-commutes-bulk-of-chelsea-manningssentence.html. Last access 20/04/2021.

Scott, A. O. 2016. "Review: 'Snowden,' Oliver Stone's Restrained Portrait of a Whistle-Blower." The New York Times. https://www.nytimes.com/2016/09/16/movies/snow den-review-oliver-stone-joseph-gordon-levitt.html. Last access 20/04/2021.

Vandekerckhove, Wim, et al. 2014. "Understandings of Whistleblowing: Dilemmas of societal culture." In International Handbook of Whistleblowing Research, edited by Wim Vandekerckhove et al, 37-70. Cheltenham: Edward Elgar.

Vandekerckhove, Wim and Suzan Langenberg. 2012. "Can We Organize Courage? Implications of Foucault's Parrhesia." Electronic Journal of Business Ethics and Organization Studies, 17: 35-44.

Weiskopf, Richard and Yvonne Tobias-Miersch. 2016. "Whistleblowing, Parrhesia and the Contestation of Truth in the Workplace." Organization Studies, 37: 1621-1640.

Žižek, Slavoj. 2011. "Good Manners in the Age of WikiLeaks." Los Angeles Review of Books. https://www. Irb.co.uk/the-paper/v33/n02/slavoj-zizek/good-manners-inthe-age-of-wikileaks. Last access 20/04/2021.

----, 2013. Less than Nothing: Hegel and the Shadow of Dialectical Materialism. London/New York: Verso.

Zuboff, Shoshana. 2020. The Age of Surveillance Capitalism: The Fight for a Human Future and the New Frontier of Power. New York: Public Affairs.

\section{Filmography}

A Nightmare on Elm Street. (1984). Directed by Wes Craven. USA: New Line Home Entertainment. DVD.

All the President's Men. (1976). Directed by Alan J. Pakula. USA: Warner Brothers Entertainment. DVD.

Born on the $4^{\text {th }}$ of July. (1989). Directed by Oliver Stone. GER: Universal Pictures Germany. Blu Ray.

Citizenfour. (2014). Directed by Laura Poitras. USA: Praxis Films. DVD.

Dark Waters. (2019). Directed by Todd Haynes. UK: Universal Pictures. DVD.

Erin Brockovich. (2000). Directed by Steven Soderbergh.
USA: Sony Pictures Home Entertainment. Blu Ray. Informant! (2009). Directed by Steven Soderbergh. USA: Warner Home Video. DVD.

It Follows. (2014). Directed by David Mitchell. GER: Weltkino Filmverleih. Blu Ray.

North Country. (2005). Directed by Niki Caro. USA:

Warner Home Video. DVD.

Official Secrets. (2019). Directed by Gavin Hood. USA:

Paramount. DVD.

On the Waterfront. (1954). Directed by Elia Kazan. USA:

Sony Pictures Home Entertainment. DVD.

Platoon. (1986). Directed by Oliver Stone. USA: 20th

Century fox Home Entertainment. DVD.

Serpico. (1973). Directed by Sidney Lumet. GER:

Arthaus. Blu Ray.

Silkwood. (1983). Directed by Mike Nichols. USA: MGM

Home Entertainment. DVD.

Snowden. (2916). Directed by Oliver Stone. GER: Universum Film GmbH. Blu Ray.

Star Wars Episodes I-III. (1999-2005). Directed by

George Lucas. USA: 20th Century fox Home Entertainment. DVD.

The China Syndrome. (1978). Directed by James Bridges. USA: Sony Pictures Home Entertainment. Blu Ray.

The Electric Horseman. (1979). Directed by Sidney

Pollack. GER: Koch Media. Blu Ray.

The Fifth Estate. (2013). Directed by Bill Condon. GER:

Constantin Film. Blu Ray.

The Shining. (1980). Directed by Stanley Kubrick. USA:

Warner Home Video. DVD.

Valkyrie. (2008). Directed by Brian Singer. USA: 20th

Century Fox Home Entertainment. Blu Ray. 